\title{
Hubungan asupan vitamin D dengan kadar 25(OH)D serum pada ibu hamil trimester III etnis minangkabau
}

\author{
Athica Oviana ${ }^{1,2}$, Andi Friadi ${ }^{1,3}$, Cimi IImiawati ${ }^{4}$ \\ 1. Program Studi Pascasarjana Ilmu Kebidanan, Fakultas Kedokteran, Universitas Andalas; 2. \\ Program Studi D-III Kebidanan, STIKes Perintis Padang; 3. Bagian Obstetri dan Ginekologi, Fakultas \\ Kedokteran, Universitas Andalas; 4. Bagian Farmakologi, Fakultas Kedokteran, Universitas Andalas
}

Korespondensi: Cimi Ilmiawati; e-mail: ilmiawati@med.unand.ac.id

\begin{abstract}
Abstrak
Tujuan: Untuk mengetahui hubungan asupan vitamin D dengan kadar 25(OH)D serum pada ibu hamil trimester III etnis Minangkabau. Metode: Penelitian dengan desain cross-sectional di wilayah kerja Puskesmas Andalas Padang terhadap 88 orang subjek ibu hamil trimester III etnis Minangkabau. Penelitian dilakukan dengan teknik wawancara terstruktur menggunakan kuesioner dan food recall 24 jam selama dua hari dan pemeriksaan kadar 25(OH)D serum dengan metode ELISA. Hasil: Hampir separuh subjek penelitian ( $\mathrm{n}=40 ; 45,5 \%)$ termasuk dalam kategori defisiensi vitamin $\mathrm{D}(<20 \mathrm{ng} / \mathrm{mL})$.

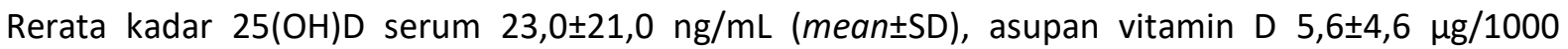
kkal/hari. Uji korelasi Pearson menunjukkan tidak terdapat hubungan antara asupan vitamin D dengan kadar 25(OH)D serum pada ibu hamil trimester III ( $r=0,161 ; p=0,134)$. Simpulan: Tidak terdapat hubungan antara asupan vitamin D dengan kadar $25(\mathrm{OH}) \mathrm{D}$ serum pada ibu hamil trimester III etnis Minangkabau.
\end{abstract}

Kata kunci: ibu hamil; 25(OH)D; vitamin D

\begin{abstract}
Objective: To determine the association between vitamin $D$ intake and serum 25(OH)D levels in third trimester pregnant women of Minangkabau ethnicity. Methods: A cross-sectional study was conducted on 88 third trimester pregnant women in Padang. Data were obtained by structured interview technique using a standardized questionnaire and 24-hour food recall for two days, serum $25(\mathrm{OH}) \mathrm{D}$ level was measured by ELISA method. Results: Nearly half of the subjects ( $n=40 ; 45.5 \%)$ were categorized into vitamin $D$ deficiency $(<20 \mathrm{ng} / \mathrm{mL}$ ). Serum $25(\mathrm{OH})$ D level was $23 \pm 21.1 \mathrm{ng} / \mathrm{mL}$ (mean $\pm S D)$, vitamin $D$ intake was $5.6 \pm 4.6 \mu \mathrm{g} / 1000 \mathrm{kcal} /$ day (mean $\pm S D$ ). Pearson correlation test showed no statistically significant association between vitamin $D$ intake and serum 25(OH)D level $(r=0.161 ; p=0.134)$. Conclusion: Vitamin $D$ intake is not associated with serum $25(O H) D$ level in third trimester pregnant women of Minangkabau ethnicity.
\end{abstract}

Keywords: pregnant women; 25(OH)D; vitamin D 


\section{PENDAHULUAN}

Asupan diet merupakan salah satu penentu status vitamin $D$, termasuk konsumsi sumber vitamin $D$ alami seperti minyak hati ikan, makanan yang difortifikasi dan suplemen. Asupan akan dipengaruhi oleh budaya praktik diet dan kebijakan nasional. ${ }^{1}$ Ada beberapa sumber makanan alami vitamin D seperti ikan berlemak, minyak hati ikan, dan kuning telur. ${ }^{2}$ Studi potong lintang di Inggris menunjukkan bahwa konsentrasi 25(OH)D plasma lebih rendah pada vegetarian dan vegan dibandingkan dengan pemakan daging. ${ }^{3}$ Studi Hoorn di Belanda menunjukkan bahwa salah satu faktor penentu status vitamin $D$ adalah mengonsumsi makanan yang telah difortifikasi (3 IU per gam) dan penggunaan suplemen vitamin $D^{4}$, serta peningkatan dosis vitamin $D$ pada orang dewasa dan anak-anak juga berpengaruh terhadap konsentrasi $25(\mathrm{OH}) \mathrm{D}$ serum. ${ }^{5}$ Asupan diet dilakukan dengan metode 24-hour dietary recall $^{6}$ dan pengukurannya menggunakan program Nutrisurvey 2007.

Kekurangan vitamin D pada saat hamil memiliki dampak pada janin dan bayi baru lahir. ${ }^{8}$ Penelitian yang dilakukan di Amerika serikat pada wanita hamil yang mengalami insufisiensi vitamin $D$ dengan kadar 25(OH)D serum $<75 \mathrm{nmol} / \mathrm{L}$ dikaitkan dengan peningkatan risiko preeklamsia. ${ }^{9}$

Selain itu defisiensi vitamin $D$ pada ibu hamil dengan kadar serum 25(OH)D $<50$ $\mathrm{nmol} / \mathrm{L}$ dikaitkan dengan peningkatan risiko diabetes melitus gestasional, kelahiran prematur dan usia kecil untuk kehamilan. ${ }^{10}$ Risiko vaginosis bakterialis dan bayi berat lahir rendah juga ditemukan pada wanita hamil yang mengalami defisiensi kadar 25(OH)D serum $<50$ nmol/L. ${ }^{11}$

Penelitian di Cina pada 1.635 sampel (545 wanita yang melahirkan bayi makrosomia dan 1.090 kontrol), di antara wanita yang melahirkan bayi dengan makrosomia 71,2\% wanita memiliki kadar 25(OH)D serum $<50 \mathrm{nmol} / \mathrm{L}$, untuk wanita dengan kadar 25(OH)D serum $<50 \mathrm{nmol} / \mathrm{L}$ mereka memiliki $33 \%$ peningkatan risiko makrosomia, dan risiko makrosomia meningkat secara signifikan apabila mengalami penurunan kadar 25(OH)D serum, dan dianjurkan konsumsi suplemen vitamin D pada masa kehamilan. ${ }^{12}$

Temuan penelitian di Vietnam pada wanita hamil $60 \%$ memiliki kadar $25(\mathrm{OH}) \mathrm{D}$ serum (<75 nmol/L) 13, di Kenya melaporkan bahwa $21 \%$ wanita mengalami defisiensi kadar 25(OH)D serum ( $<50 \mathrm{nmol} / \mathrm{L}$ dan $51 \%$ wanita mengalami insufisiensi dengan memiliki kadar 25(OH)D serum $\quad<75$ $\mathrm{nmol} / \mathrm{L}){ }^{14}$ Penelitian yang dilakukan di Cina ditemukan sebanyak $63,7 \%$ wanita hamil mengalami defisiensi 25(OH)D $(<50,0 \mathrm{nmol} / \mathrm{L}) .{ }^{15}$

Penelitian yang dilakukan pada wanita sehat di Sumatera Utara selama musim kemarau menunjukkan bahwa 95\% subjek mengalami defisiensi kadar 25(OH)D serum. ${ }^{16}$

Penelitian baru-baru ini yang dilakukan pada wanita dewasa muda etnis 
Minangkabau mendapatkan bahwa 97\% subjek mengalami defisiensi kadar serum 25(OH)D dan dari hasil penelitian tersebut didapatkan bahwa kualitas tidur, asupan diet, dan penggunaan tabir surya merupakan prediktor kadar 25(OH)D serum. ${ }^{17,18} \mathrm{Hal}$ ini menunjukkan bahwa dengan memperhatikan asupan nutrisi seperti asupan vitamin D tapi tidak menjamin kecukupan vitamin $D$. Mengingat tingginya angka defisiensi kadar 25(OH)D serum pada wanita sehat di Indonesia, dan kebiasaan wanita hamil di Sumatera Barat yang tidak memperhatikan sumber makanan serta masih terbatasnya penelitian pada ibu hamil, maka penulis merasa perlu untuk meneliti hubungan asupan vitamin $D$ dengan kadar $25(\mathrm{OH}) \mathrm{D}$ serum pada ibu hamil trimester III etnis Minangkabau.

\section{METODE}

Penelitian ini merupakan penelitian observasional analitik dengan rancangan cross-sectional. Penelitian dilakukan di wilayah kerja Puskesmas Andalas dan Laboratorium Biomedik Fakultas Kedokteran Universitas Andalas Padang pada bulan Februari 2019 sampai dengan Juni 2019. Populasi dalam penelitian ini adalah seluruh ibu hamil. Responden dalam penelitian ini sebanyak 88 orang ibu hamil trimester III etnis Minangkabau (dapat mengidentifikasi suku Minangkabau dari ayah dan ibu).

Penelitian ini dilakukan dengan teknik wawancara terstruktur dan pemeriksaan laboratorium. Wawancara dilakukan dengan menggunakan kuesioner dan food recall 24 jam selama 2 hari untuk mendapatkan data mengenai asupan vitamin D. Penelitian ini telah disetujui oleh komite etik Fakultas Kedokteran Unand (Approval No.005/KEP/FK/2019). Penelitian dilakukan dengan pengambilan $2 \mathrm{~mL}$ darah ibu hamil, kemudian sampel darah di sentrifugasi kemudian di ambil serumnya untuk melihat kadar 25(OH)D serum dengan menggunakan Elisa Reader (25(OH)D) ELISA Kit (Can-VD-510) yang diproduksi oleh Diagnostic Biochem Canada $\left(\mathrm{DBC}^{\circledR}\right)$.

Uji normalitas data menggunakan Kolmogorov Smirnov ( $\geq 50$ sampel). Hasil uji menunjukkan bahwa data terdistribusi normal $(p>0,05)$ untuk kadar 25(OH)D Serum, dan Asupan Vitamin D. Analisis statistik data dilakukan dengan uji parametrik (Korelasi Pearson) dan dari hasil penelitian diketahui bahwa tidak terdapat hubungan yang signifikan antara asupan vitamin D dengan kadar $25(\mathrm{OH}) \mathrm{D}$ serum pada ibu hamil trimester III etnis Minangkabau dengan nilai $p=0,134$.

\section{HASIL DAN PEMBAHASAN}

Karakteristik subjek penelitian dilihat dari umur ibu, gravidarum, Usia kehamilan ibu saat ini (minggu).

Hasil analisis univariat pada (Tabel 1) menunjukkan bahwa rata-rata subjek penelitian memiliki umur 30,65 tahun dengan sebagian besar usia 20-35 tahun sebanyak $76,1 \%$, kemudian pada subjek penelitian berdasarkan gravidarum dapat dilihat bahwa rata-rata subjek penelitian 
sudah lebih dari satu kali hamil yaitu sebanyak 2,55 dengan sepertiga subjek penelitian gravidarum ke-3 sebanyak $33,0 \%$, dan dapat dilihat pada subjek penelitian berdasarkan usia kehamilan ibu saat ini memiliki umur kehamilan 32,65 minggu. Berdasarkan kadar 25(OH)D serum dapat dilihat bahwa rata-rata kadar 25(OH)D serum subjek penelitian 23,00 $\mathrm{ng} / \mathrm{mL}$ dengan yang berada dalam status defisiensi vitamin D yaitu sebanyak $45,5 \%$. Berdasarkan asupan vitamin D dapat

\section{Tabel 1. Karakteristik subjek penelitian}

\begin{tabular}{cccccccc}
\hline Karakteristik & $f$ & $\%$ & Mean & SD & Min & Max & Median \\
\hline Umur ibu (tahun) & 88 & 100 & & & & & \\
$<20$ & 3 & 3,4 & 30,7 & 5,3 & 17 & 41 & 30,5 \\
$20-35$ & 67 & 76,1 & & & & & \\
$>35$ & 18 & 20,5 & & & & & \\
Gravidarum & 88 & 100 & & & & & \\
1 & 16 & 18,2 & & & & & \\
2 & 27 & 30,7 & & & & & \\
3 & 29 & 33 & 2,6 & 1,1 & 1 & 5 & 3 \\
4 & 13 & 14,8 & & & & & \\
5 & 3 & 3,4 & & & & & \\
Usia kehamilan ibu (minggu) & 88 & 100 & 32,7 & 3,7 & 28 & 40 & 32 \\
Kadar 25 (OH)D Serum (ng/ml) & 88 & 100 & & & & & \\
Defisiensi $<20$ & 40 & 45,5 & 23,0 & 10,0 & 7,4 & 51,5 & 21,1 \\
Insufisiensi 20-31 & 32 & 36,4 & & & & & \\
Sufisiensi 32-100 & 16 & 18,2 & & & & & \\
Asupan Vitamin D ( $\mu$ /1000kkal/hari) & 88 & 100 & 5,6 & 3,9 & 0,0 & 16,4 & 4,6 \\
\hline
\end{tabular}

Analisis hubungan asupan vitamin D dengan kadar 25(OH)D serum dilakukan dengan uji Pearson (Gambar 1) dan dari hasil penelitian diketahui bahwa tidak terdapat hubungan yang signifikan antara asupan vitamin D dengan kadar 25(OH)D serum pada ibu hamil trimester III dengan nilai $p=0,134$. dilihat bahwa median asupan vitamin D 4,64 $\mathrm{\mu g} / \mathrm{h} / 1000 \mathrm{kkal} / \mathrm{hari}$, dan sebagian subjek penelitian rata-rata asupan vitamin D yaitu sebanyak 5,58 $\mathrm{\mu g} / \mathrm{hari} / 1000 \mathrm{kkal}$. Berdasarkan sumber vitamin $D$ subjek penelitian pada (Tabel 2) sebagian besar subjek penelitian ini sumber makanan dengan kandungan vitamin $D$ yang tinggi berasal dari protein hewani berupa ikan (ikan tongkol) sebagai sumber proteinnya $(85,23 \%)$. 
dewasa dan anak-anak juga berpengaruh terhadap konsentrasi $25(\mathrm{OH}) \mathrm{D}$ serum. ${ }^{5}$

Tabel 2. Sumber Vitamin D subjek penelitian

\begin{tabular}{lccccc}
\hline Sumber vitamin D & $\begin{array}{c}\text { Kandungan vit. D } \\
(\mathrm{mg} / 100 \mathrm{~g})\end{array}$ & $\begin{array}{c}\text { Konsumsi } \\
\text { per hari }(\mathrm{g})\end{array}$ & $\begin{array}{c}\text { Asupan vit. D } \\
(\mu \mathrm{g} / \mathrm{hari})\end{array}$ & $f$ & $\%$ \\
\hline Ikan tongkol & 5 & $45-75$ & $2,3-3,8$ & 75 & 85,2 \\
Telur ayam & 1 & $30-65$ & $0,3-0,6$ & 49 & 55,7 \\
Ikan lele & 10 & $75-100$ & $7,5-10$ & 38 & 43,2 \\
Susu & 7 & $30-40$ & $2,1-2,8$ & 23 & 26,1 \\
Ikan mujair & 1 & $75-100$ & $0,8-1$ & 10 & 11,4 \\
Ikan tongkol pindang & 5 & $75-100$ & $3,8-5$ & 8 & 9,1 \\
iikan asin teri & 2 & $25-75$ & $0,5-1,5$ & 8 & 9,1 \\
Energen & 2,5 & $25-30$ & $0,6-0,8$ & 2 & 2,3 \\
Ikan kakap & 1 & 100 & 100 & 2 & 2,3 \\
Ikan pindang selar kecil & 15 & 100 & 15 & 1 & 1,1 \\
Ikan asin goreng & 9 & 100 & 9 & 1 & 1,1 \\
Kepiting laut & 4 & 100 & 4 & 1 & 1,1 \\
Belut & 12 & 75 & 9 & 1 & 1,1 \\
Ikan asin japuh & 20 & 75 & 15 & 1 & 1,1 \\
Ikan pindang kembung & 15 & 75 & 11,3 & 1 & 1,1 \\
Kuning telur ayam & 8 & 30 & 2,4 & 1 & 1,1 \\
Telur puyuh & 5 & 30 & 1,5 & 1 & 1,1 \\
Sosis & 1 & 30 & 0,3 & 1 & 1,1 \\
\hline
\end{tabular}

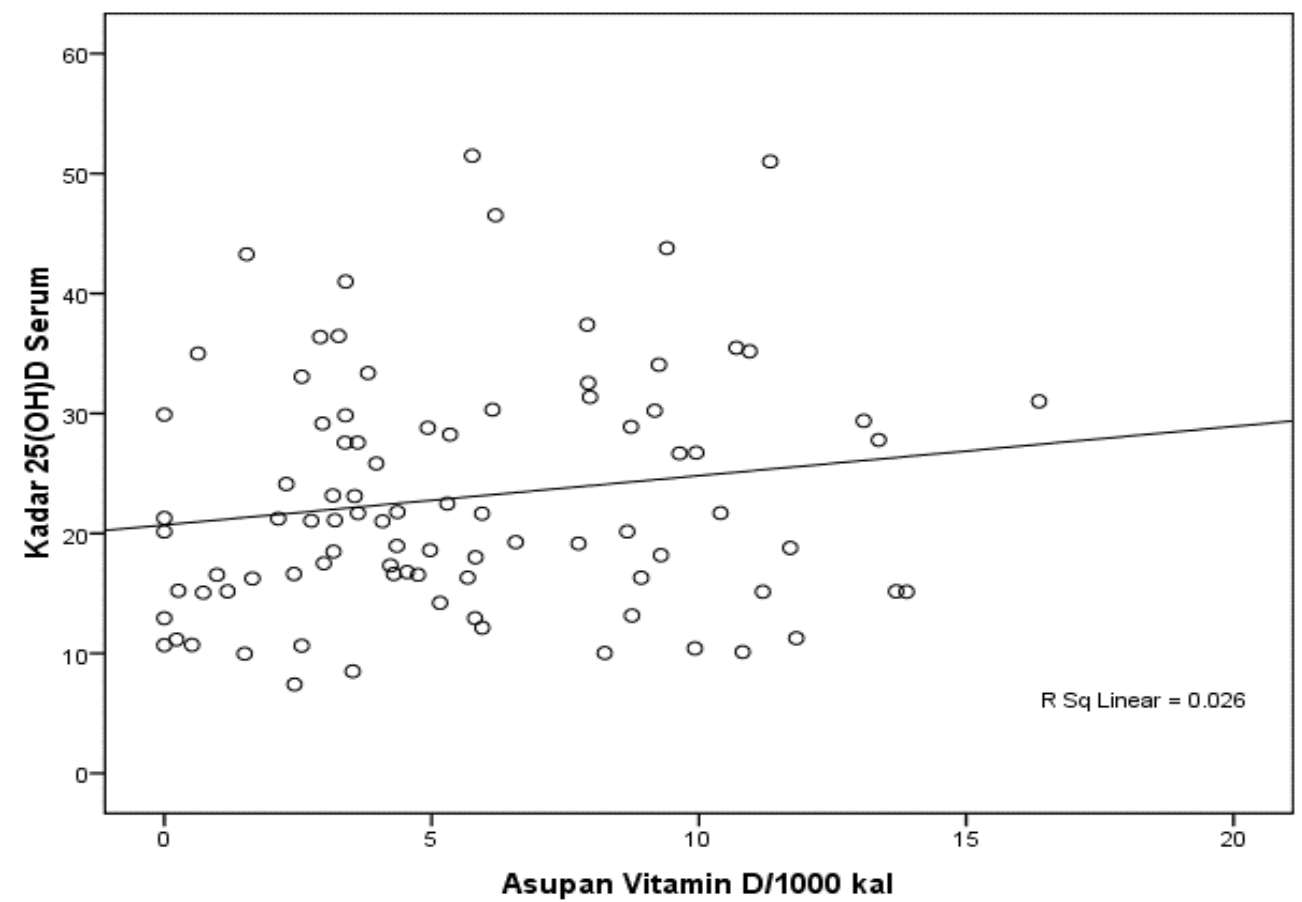

Gambar 1. Scatter Plot Hubungan asupan vitamin D dengan kadar 25(OH)D serum $(r=0,161 ; p=0,134)$ 
Hasil penelitian terdahulu yang dilakukan $^{17,18}$ di kota Padang pada perempuan remaja akhir yang menyatakan bahwa terdapat hubungan signifikan antara asupan vitamin D dengan kadar 25(OH)D serum dengan sebagian besar subjek penelitian memiliki asupan vitamin D yang rendah yaitu sebanyak $96,2 \%$ dan asupan vitamin $D$ tertinggi hanya 9,38 $\mu \mathrm{g} /$ hari/1000 kkal, dan asupan vitamin $D$ merupakan prediktor yang mempengaruhi variabilitas kadar 25(OH)D serum. Hasil studi potong lintang di Inggris menunjukkan bahwa konsentrasi $25(\mathrm{OH}) \mathrm{D}$ plasma lebih rendah pada vegetarian dan vegan dibandingkan dengan pemakan daging. $^{3}$

Sementara pada hasil penelitian ini tidak terdapat hubungan antara asupan vitamin D dengan kadar 25(OH)D serum dengan ditemukan bahwa tidak ada dari subjek penelitian yang mencukupi angka kecukupan vitamin D menurut Kemenkes dan IOM yaitu $15 \mu \mathrm{g} /$ hari. ${ }^{19} \mathrm{Hal}$ ini terjadi karena berdasarkan analisis Nutrisurvey dapat diketahui bahwa sebagian besar subjek penelitian ini sumber makanan dengan kandungan vitamin $D$ yang tinggi berasal dari protein hewani berupa ikan (ikan tongkol) sebagai sumber proteinnya $(85,23 \%$ ) (tabel 2). Sementara ikan tongkol merupakan sumber vitamin $D$ dengan kandungan vitamin $D$ hanya $5 \mu \mathrm{g}$, sehingga tidak ada dari subjek penelitian yang mencukupi angka kecukupan vitamin D menurut Kemenkes dan IOM. Selain itu pada hasil penelitian ini ditemukan subjek penelitian memiliki kebiasaan pola makan yang tidak teratur serta jarang memperhatikan asupan nutrisi yang akan dikonsumsi, sehingga berdasarkan analisis Nutrisurvey dapat diketahui bahwa ratarata asupan vitamin $D$ pada subjek penelitian ini 5,58 $\mathrm{\mu g} / \mathrm{hari} / 1000 \mathrm{kkal}$ dengan asupan tertinggi 16,36 $\mu \mathrm{g} /$ hari/1000 kkal. Jadi hal inilah yang menyebabkan asupan vitamin $\mathrm{D}$ tidak berhubungan dengan kadar 25(OH)D serum.

\section{SIMPULAN}

Tidak terdapat hubungan asupan vitamin D dengan kadar 25(OH)D serum pada ibu hamil trimester III etnis Minangkabau.

\section{DUKUNGAN FINANSIAL}

Pendanaan Studi ini didukung oleh hibah dari Kementerian Riset, Teknologi, dan Pendidikan Tinggi Indonesia (Kemenristekdikti) dan dari Universitas Andalas (Hibah Percepatan Guru Besar Tahun 2018) untuk Cl.

\section{UCAPAN TERIMA KASIH}

Para penulis mengucapkan Terima kasih dan mengapresiasi semua ibu hamil yang berpartisipasi dalam penelitian ini. Terima kasih khusus kepada Ibu Lola Alviche, Ibu Rati Purwati dan Bapak Muhammad Diki Juliandi atas kontribusi dan bantuan mereka selama pengumpulan data. 


\section{DAFTAR PUSTAKA}

1. Lamberg-Allardt C, Brustad M, Meyer HE, Steingrimsdottir L. Vitamin D - a systematic literature review for the 5th edition of the Nordic Nutrition Recommendations. Food Nutr Res. 2013; 57. doi: 10.3402/fnr.v57i0.22671. [PubMed].

2. Institute of Medicine. Dietary Reference Intakes for Calcium and Vitamin D. Washington DC: The National Academies Press; 2011. doi: 10.17226/13050.

3. Crowe FL, Steur M, Allen NE, Appleby PN, Travis RC, Key TJ. Plasma concentrations of 25hydroxyvitamin $D$ in meat eaters, fish eaters, vegetarians and vegans: results from the EPIC-Oxford study. Public Health Nutr. 2011; 14(2):340-6. doi: 10.1017/S1368980010002454. [PubMed].

4. van Dam RM, Snijder MB, Dekker JM, Stehouwer CD, Bouter LM, Heine RJ, et al. Potentially modifiable determinants of vitamin $D$ status in an older population in the Netherlands: the Hoorn Study Am J Clin Nutr. 2007; 85(3):755-61. doi: 10.1093/ajcn/85.3.755. [PubMed].

5. Cranney A, Horsley T, O'Donnell S, Weiler H, Puil L, Ooi D, et al. Effectiveness and safety of vitamin $D$ in relation to bone health. Evid Rep Technol Assess (Full Rep). 2007; 158:1-235. [PubMed] [PMC free article].

6. Salvador Castell G, Serra-Majem L, Ribas-Barba L. What and how much do we eat? 24-hour dietary recall method. Nutr Hosp. 2015; 31(Suppl 3):46-8. doi: 10.3305/nh.2015.31.sup3.8750. [PubMed]

7. EBISpro. NutriSurvey software. German. 2007. Diunduh dari: [Link].

8. Urrutia-Pereira $M$, Solé $D$. Deficiência de vitamina $D$ na gravidez e o seu impacto sobre o feto, $o$ recém-nascido e na infância. Revista Paulista de Pediatria. 2015; 33(1):104-113. doi: 10.1016/j.rpped.2014.05.004.

9. Amegah AK, Klevor MK, Wagner CL. Maternal vitamin D insufficiency and risk of adverse pregnancy and birth outcomes: a systematic review and meta-analysis of longitudinal studies. PLOS ONE. 2017; 12(3): e0173605. doi: 10.1371/journal.pone.0173605. [PubMed].

10. Wei SQ, Qi HP, Luo ZC, Fraser WD. Maternal vitamin D status and adverse pregnancy outcomes: a systematic review and meta-analysis. J Matern Fetal Neonatal Med. 2013; 26(9):889-99. doi: 10.3109/14767058.2013.765849. [PubMed]

11. Aghajafari F, Nagulesapillai T, Ronksley PE, Tough SC, O'Beirne M, Rabi DM. Association between maternal serum 25-hydroxyvitamin $D$ level and pregnancy and neonatal outcomes: systematic review and meta-analysis of observational studies. BMJ. 2013;346:f1169. doi: 10.1136/bmj.f1169.

12. Wen J, Kang C, Wang J, Cui X, Hong $Q$, Wang $X$, et al. Association of maternal serum 25hydroxyvitamin $D$ concentrations in second and third trimester with risk of macrosomia. Scientific Reports. 2018; 8:6169. doi: 10.1038/s41598-018-24534-5.

13. Hanieh S, Ha TT, Simpson JA, Thuy TT, Khuong NC, Thoang DD, et al. Maternal vitamin D status and infant outcomes in rural Vietnam: a prospective cohort study. PLoS ONE. 2014; 9(6):e99005. doi: 10.1371/journal.pone.0099005. [PubMed].

14. Toko EN, Sumba OP, Daud II, Ogolla S, Majiwa M, Krisher JT, et al. Maternal Vitamin D Status and Adverse Birth Outcomes in Children from Rural Western Kenya. Nutrients. 2016; 8(12):794. doi: 10.3390/nu8120794. [PMC free article]. 
15. Yuan Y, Liu H, Ji C, Guo X, Hu L, Wen J, et al. Association of maternal serum 25-hydroxyvitamin D concentrations in second trimester with delivery mode in a Chinese population. Int J Med Sci. 2017; 14(10):1008-1014. doi: 10.7150/ijms.20337. [PubMed].

16. Sari DK, Damanik HA, Lipoeto NI, Lubis Z. Are avoiding sunlight exposure and low physical activity resulting micro evolution in tropical country women?. Scientific Research Journal. 2013; 1(3):1826.

17. Silvia $E$, Nasrul E, Ilmiawati C. Hubungan kadar 25-hidroksivitamin D serum dengan latensi tidur pada perempuan remaja akhir. Jurnal Kesehatan Andalas. 2019; 8(1):124-130. doi: 10.25077/jka.v8.i1.p124-130.2019.

18. Silvia E. Analisis Beberapa Faktor yang Berhubungan dengan Kadar 25-Hidroksivitamin D Serum pada Perempuan Remaja Akhir. [Thesis]. Padang: Universitas Andalas; 2018. Diunduh dari: [Link]. 19. Kementerian Kesehatan RI. Pedoman gizi seimbang. Jakarta: Kementerian Kesehatan RI; 2014. 